\title{
PREVALENCE OF BRUCELLOSIS IN SMALL RUMINANTS IN THREE REGIONS OF GHANA
}

\author{
T. A. JARIKRE ${ }^{1}$, B. O. EMIKPE ${ }^{1,2}$, R. D. FOLITSE ${ }^{2}$, T. K. ODOOM ${ }^{3}$, \\ A. FUSEINI ${ }^{4} \&$ E. SHAIBU 5 \\ ${ }^{1}$ Department of Veterinary Pathology, University of Ibadan, Ibadan, Nigeria; ${ }^{2}$ School of \\ Veterinary Medicine, Kwame Nkrumah University of Science and Technology, Ghana; \\ ${ }^{3}$ Ministry of Food and Agriculture, Accra Central Laboratory, Accra, Ghana; ${ }^{4}$ Ministry \\ of Food and Agriculture, Tamale Abattoir, Tamale, Ghana; ${ }^{5}$ Ministry of Food and \\ Agriculture, Kumasi Abattoir, Kumasi, Ghana
}

\begin{abstract}
Summary
Jarikre, T. A., B. O. Emikpe, R. D. Folitse, T. K. Odoom, A. Fuseini \& E. Shaibu, 2015. Prevalence of brucellosis in small ruminants in three regions of Ghana. Bulg. J. Vet. Med., 18, No 1, 49-55.

Information on the prevalence of important reproductive zoonoses in West African countries other than Nigeria had been scanty in literature. This study estimates the prevalence of brucellosis in sheep and goats from Northern, Ashanti and Greater Accra regions of Ghana. Tissues/swabs (319) and serum (370) samples were collected from sheep and goats comprising male and female West African Dwarf (WAD) and Sahelian breeds between 1 to 4 years of age in the regions. These were screened for brucellosis using Modified Ziehl Neelsen (MZN) staining method and the Rose Bengal Plate Test (RBPT). A seroprevalence of $13.3 \%$ was recorded while $17.0 \%$ were positive with modified ZN staining. Goats $(10 \%)$ and female animals $(7.0 \%)$ had slightly higher seroprevalence. Adult animals of above two years had prevalence of $92.0 \%$ while WAD breed had the highest prevalence of $63.0 \%$ with $2.7 \%$ in female WAD. More seropositive animals were found from Ashanti region than other regions. Due to the zoonotic and economic implications of the disease, there is the need to embark on the strict control strategies including vaccination of small ruminants against brucellosis.
\end{abstract}

Key words: brucellosis, Ghana, MZN staining method, seroprevalence, small ruminants

\section{INTRODUCTION}

Ghana hosts a large number of small ruminants that are raised under extensive pastoral production system and in adjunct to crop production (Karbo \& Agyare, 2000). Despite the country's vast resources of forage, its livestock resource base is modest with about 1.3 million cattle, 2.5 million sheep and 2.7 million goats (ADF, 2001). The total estimated livestock population of Ghana is about 58.4 million of which Northern Ghana accounts for over $50 \%$ of agricultural 
production, while Ashanti and Greater Accra are of the receiving end in the agricultural production chain due to the large human population (SRID, 2010).

Ghana seems not to optimally utilise this resource as the country still relies on major import of small ruminants (Karbo \& Agyare, 2000). Despite this obvious limitation, disease is a major factor that limits the economic return from small ruminant production. A disease that hampers the productivity of small ruminants is brucellosis (Megid et al., 2010).

Brucellosis is recognised as one of the most important zoonotic diseases across the world as it poses a major threat to both human health and animal populations (Cutler \& Cutler, 2006; Mensal et al., 2011). The World Health Organization considers it as a neglected zoonosis, because adequate control programmes were not in place in numerous countries despite its huge impact on human and animal health, also on the economy (Holt et al., 2011). Brucellosis poses a barrier to the trade of animals and their products, and the associated reproductive wastage/infertility is enormous (Godfroid et al., 2011).

Small ruminant brucellosis is mostly caused by Brucella melitensis (Prahad et al., 1997; Omer et al., 2002). Brucella ovis is also important, causing orchitis and epididymitis in rams but it is not a cause of natural infection in goats (Smith \& Sherman, 1996). Persistent infection is a common feature of the disease with frequent shedding of the bacterium in body secretions (Tanko et al., 2013). Brucellosis has been reported in small ruminants from different parts of the world in Somalia (Falade \& Hussein, 1997), Eritrea (Omer et al., 2000) Ethiopia (Teshale et al., 2006), Sudan (El-Ansary et al., 2001) and Nigeria (Shehu et al., 1999). In Ghana, Aning et al. (2002) reported a high prevalence of $B$. abortus antibodies in raw cow milk taken from retailers and wholesalers in Accra and Kumasi. Also, the disease in cattle was reported from the coastal and northern savannah zones (Turkson \& Boadu, 1992) as well as the middle forest belt by Kubuafor et al. (2000). The detection of B. abortus as well as several other pathogens in raw milk from Ghana in the past has not raised the needed concern as expected (Ayebo \& Assoku, 1976; Mensal et al., 2011) and in recent years, the marketing of fresh dairy from cattle and goat in Ghana, especially in the urban and peri-urban areas has increased considerably in response to a growing demand for such products. The dearth of information on this disease and its prevalence in small ruminants require the need to study its occurrence, for generation of baseline data and policy formulation on zoonosis control in small ruminants and other livestock.

\section{MATERIALS AND METHODS}

\section{Study area}

The study was carried out in three regional abattoirs and slaughter house; Accra, Kumasi and Tamale between October and November 2013. Tamale municipal abattoir is located in Shishegu, a suburb of Tamale Metropolis between latitudes $9^{\circ} .15^{\prime}-9^{\circ} .30^{\prime} \mathrm{N}$ and longitudes $0^{\circ} .45^{\prime}$ and $10^{\circ} \mathrm{W}$. Kumasi abattoir is located at $6^{\circ} 39^{\prime} 36.6^{\prime \prime} \mathrm{N}$ Latitude and $1^{\circ} 36^{\prime} 15.4^{\prime \prime} \mathrm{W}$ Longitude, in the Kumasi city of Ghana, and the Accra slaughter house is in Accra metropolitan area.

\section{Animals}

A total of 370 sheep and goats were sampled randomly across the three regions. These comprised the West African dwarf 
(WAD) and Sahelian breeds of both species common in the regions. They were categorised as young adults (less than 2 years of age) and adults (above 2 years of age). Goats consisted of 268 adults and 18 young adults and sheep - of 72 adults and 12 young adults.

\section{Serum collection}

A cross-sectional study was conducted to determine the occurrence of brucellosis in small ruminants. Serological tests and questionnaire survey were used as a tool to determine the prevalence and assess the associated risk factors. Blood samples were collected from the sheep and goats in a simplified random approach before slaughter. Approximately $7-10 \mathrm{~mL}$ of blood was collected from jugular vein using plain vacutainer tubes and needles. Individual tubes were identified using numbers and alphabets to indicate their location and source. The tubes were left tilted overnight at room temperature to allow clotting. The sera were separated from the clot (unretract blood centrifuged) by siphoning into sterile test tubes. The 370 serum samples from 286 goats and 84 sheep were transported in icebox to the Veterinary laboratory in Accra and stored at $-20{ }^{\circ} \mathrm{C}$ until Rose Bengal Plate Test (RBPT) was carried out using standard techniques.

\section{Tissue /swab collection}

Tissues from placenta (6), foetal fluid (37), vaginal (100), preputial (38) and nasal (138) swabs were screened using Modified Ziehl Neelsen (MZN) staining technique as described by Balows et al. (1991) \& Miller (1991). The distribution of all animals examined is presented in Table 1.

\section{Modified Ziehel Neelsen acid fast stain}

Tissues and swabs were smeared lightly on glass slides and allowed to air dry for a few minutes. The smeared slides were fixed in $70 \%$ methanol for 10 minutes. The slides were placed on staining rack and flooded with carbol fuchsin and allowed to stain for 3 minutes before thorough rinsing with water. Slides were decolourised with 5\% sulphuric acid for 30 seconds, rinsed with water, counterstained with methylene blue for 20 seconds and finally rinsed with water and air dried. Stained smears were examined under Olympus microscope using oil immersion for detailed morphology. Samples with stained characteristic red-pinkish coccobaccili were recorded positive (Balowa et al., 1991).

\section{Rose Bengal plate test}

It was carried out using standard Rose Bengal Plate Test antigen obtained from

Table 1. Number and percentage of sheep and goats examined

\begin{tabular}{lccccc}
\hline & \multicolumn{2}{c}{ Goats } & \multicolumn{2}{c}{ Sheep } & \multirow{2}{*}{ Total } \\
\cline { 2 - 5 } & WAD breed & $\begin{array}{c}\text { Sahelian } \\
\text { breed }\end{array}$ & WAD breed & $\begin{array}{c}\text { Sahelian } \\
\text { breed }\end{array}$ & \\
\hline Male & $52(14 \%)$ & $74(21 \%)$ & $24(6 \%)$ & - & $150(41 \%)$ \\
Female & $72(20 \%)$ & $88(23 \%)$ & $58(15 \%)$ & $2(1 \%)$ & $220(59 \%)$ \\
\hline Total & $124(34 \%)$ & $162(44 \%)$ & $82(21 \%)$ & $2(1 \%)$ & $370(100 \%)$ \\
\hline
\end{tabular}


Central Veterinary Laboratory, Weybridge U.K.PA 0060 batch 281, according to the method of Alton et al. (1975). Equal volumes $(0.03 \mathrm{~mL})$ of antigen and test serum were mixed thoroughly on the glass plate of the test box using a tooth pick and the box was hand rocked for 4 min. Samples that showed signs of agglutination were recorded as positive while those with no sign of agglutination were recorded negative.

\section{RESULTS}

The number and percentages of small ruminants examined are presented in Table 1. The study conhort comprised $78 \%$ goats and $22 \%$ sheep.

Smears from the foetal fluid and impressions from the placenta revealed red stained cocco-bacilli in pairs and a few chains. Smears from the upper respiratory tracts were negative; $17 \%$ of smears were positive for Brucella sp (reddish stained coccobacilli) - Table 2.

Serologically, there was a prevalence of $10.3 \%$ for goats and $3 \%$ for sheep. The number and percentage distribution based on sex and species of sheep and goats are presented in Table 3.

Of these 49 serologically positive animals; 45 were adult above two-year-old $(92 \%)$ and 4 young adults (8\%). Thirtyone were from the WAD breed $(63 \%)$ and 18 - from the Sahelian breed (31\%). More serologically positive animals were recorded from Kumasi, followed by those in Accra and Tamale (Table 4).

Gross examination of carcasses revealed that few of the female animals had bloody foul smelling discharges from their vulva and the uterus containing abundant odourless, dirty yellow, slightly viscid and slimy exudates. In a few gravid animals (a goat and three sheep), the uteri contained gray-yellow, pulpy floccules of detritus in between the endometrium and chorion in the intercotyledonary area. Their foetal

Table 2. Number and percentage of Brucella positive smears from sheep and goat using the modified Ziehl Neelsen staining test.

\begin{tabular}{lcccc}
\hline Tissue/swab & Goats & Sheep & Number of smears & Positive smears \\
\hline Foetal fluid & 29 & 8 & 37 & $18(5.6 \%)$ \\
Placenta & 4 & 2 & 6 & $3(0.9 \%)$ \\
Vaginal & 73 & 27 & 100 & $20(6.3 \%)$ \\
Preputial & 31 & 7 & 38 & $12(3.8 \%)$ \\
Nasal & 107 & 31 & 138 & 0 \\
\hline Total & 244 & 75 & 319 & $53(17 \%)$ \\
\hline
\end{tabular}

Table 3. Number \& percentage of animals positive in the Rose Bengal Plate Test.

\begin{tabular}{lccccc}
\hline & \multicolumn{3}{c}{ Goats } & \multicolumn{2}{c}{ Sheep } \\
\cline { 2 - 5 } & WAD breed & $\begin{array}{c}\text { Sahelian } \\
\text { breed }\end{array}$ & WAD breed & $\begin{array}{c}\text { Sahelian } \\
\text { breed }\end{array}$ & Total \\
\hline Male & $11(3 \%)$ & $11(3 \%)$ & $1(0.3 \%)$ & - & $23(6.3 \%)$ \\
Female & $9(2.4 \%)$ & $7(1.9 \%)$ & $10(2.7 \%)$ & - & $26(7 \%)$ \\
\hline Total & $20(5.4 \%)$ & $18(4.9 \%)$ & $11(3 \%)$ & - & $49(13.3 \%)$ \\
\hline
\end{tabular}


Table 4. Number \& percentage positive of animals from different locations (Rose Bengal Plate Test)

\begin{tabular}{lcccc}
\hline Location & $\begin{array}{c}\text { Screened small } \\
\text { ruminants }\end{array}$ & $\begin{array}{c}\text { Positive goats } \\
(\%)\end{array}$ & $\begin{array}{c}\text { Positive sheep } \\
(\%)\end{array}$ & $\begin{array}{c}\text { Total positive } \\
(\%)\end{array}$ \\
\hline Accra & 120 & $7(1.9 \%)$ & $4(1.1 \%)$ & $11(3.0 \%)$ \\
Kumasi & 196 & $27(7.3 \%)$ & $6(1.6 \%)$ & $33(8.9 \%)$ \\
Tamale & 54 & $3(0.8 \%)$ & $2(0.6 \%)$ & $5(1.4 \%)$ \\
\hline Total & 370 & $37(10 \%)$ & $12(3.3 \%)$ & $49(13.3 \%)$ \\
\hline
\end{tabular}

membranes and the umbilical cord were thickened and saturated with clear oedema fluid. The placental lesions were not uniform; some cotyledons appeared more or less normal and others extensively necrotic. A ram was found with moderate unilaterally inflammed testis (orchitis). Additional lesions included enlarged spleen and lymph nodes with few animals having severely pneumonic lungs and congested liver.

\section{DISCUSSION}

This appears to be the first extensive study on the prevalence of brucellosis in small ruminants from major regions of Ghana. The study showed higher prevalence of Brucella antibodies in goats than in sheep. Similar prevalence was observed in female and adult animals (above 2 years) especially of WAD breed. Occurrence in these animals further supports susceptibility of reproductive animals and the risk goat pose in the spread of brucellosis compared to sheep (Godfroid et al., 2011).

The current study revealed higher prevalence of Brucella antibodies (13.3\%) in the absence of Brucella vaccination. This is quite higher than prevalence rates of $1.7 \%$ in sheep and $1.5 \%$ in goats in Sudan (Abdala, 1966), 3.8\% in goats and $1.4 \%$ in sheep in Eritrea (Omer et al., 2000 ) and $4 \%$ in goats and $1 \%$ in sheep in eastern Sudan (El-Ansary et al., 2001). Similar to $6.01 \%$ in sheep and goats in
Kenya (Waghela, 1976), 2.8 and 5.29\% in goats and $7.2 \%$ in sheep in Somalia (Falade \& Hussein, 1997), 13.2\% in goats and $5.6 \%$ in sheep in Ethiopia (Teshale et $a l ., 2006$ ) and $6.6 \%$ in sheep and $4.75 \%$ in goats in Nigeria (Shehu et al., 1999). This is an indication of the wide spread nature of Brucella infection in Africa and a need for workable strategies for the control of the disease.

The observed difference in the prevalence of $17 \%$ from tissue/swabs using MZN and $13.3 \%$ using RBPT may have underscored the relative specificity of the serological test and the sensitivity of MZN in detecting Brucella antigen in tissues and secretions.

The prevalence of Brucella in goats from all the regions may be attributed to the uncontrolled influx from neighbouring countries, the grazing and housing of cattle with sheep and goats which increases the chance of transmission of the disease (Seleen et al., 2010). The detection of higher antibody titres in does than in bucks further suggests that female animals are generally more susceptible to Brucella infection than the males (Keppie et al., 1965).

With the economic loss resulting from brucellosis placed at $\$ 223.2$ million in Nigeria (Esuruoso, 1977), the prevalence rate of brucellosis in goats and sheep as observed in this study may lead to high economic loss and serious public health implications in Ghana. This therefore calls 
for the introduction of stringent control measures including mass vaccination for small ruminants. Large-scale sero monitoring of ruminants and humans especially personnel workers at risk should be done to assess the level of infection in both animals and humans in Ghana. Further studies are focused on the isolation and molecular characterisation of the agent in these species.

\section{ACKNOWLEDGEMENT}

Appreciation to the Centre for the Control and Prevention of Zoonoses (CCPZ), West Africa, a higher education grant supported by the MacCarthur foundation.

\section{REFERENCES}

Abdala, A. E. D., 1966. Sudan Veterinary Science. Animal Health and Husbandry, 7, 28.

Alton, G. G., L. M. Jones \& D. E. Pietz, 1975. Laboratory Techniques in Brucellosis, World Health Organisation monograph series No. 454, Geneva.

African Development Fund (ADF), 2001. Appraisal Report Livestock Development Project, Republic of Ghana. http://www. afdb.org/en/documents/document/ghanalivestock-development-project-appraisalreport-11004 (23.09.2014 date last accessed).

Aning, K. G., E. Sampane-Donkor, \& A. Omore, 2002. Analysis of milk-borne public health risks in milk markets in Ghana. Final report of the peri-urban milk marketing and public health research report. CSIR-ARI, KNUST \& International Livestock Research Institute (ILRI). 33 p.

Ayebo, A., R. \& K. G. Assoku, 1976. A study of bacteriology of raw milk produced on Accra plains of Ghana. Ghana Journal of Science, 16, 9-18.

Balows, A., W. J. Hausler, K. L. Hermann, H. D. Isenberg, \& H. J. Shadomy 1991. Manual of Clinical Microbiology, $5^{\text {th }}$ edn,
American Society for Microbiology, Washington D.C.

Corbel, M. J., 1988. Brucellosis. In: Fertility and Infertility in Veterinary Practice, $4^{\text {th }}$ edn, ed J. A. Laing, ELBS, Baillière Tindall, pp. 189-221.

Cutler, S. J., \& R. R. Cutler, 2006. Brucellosis, the most common bacterial zoonosis? The Biomedical Scientist, 50, 336-341.

El-Ansary, E. H., A. Mohammed, A. R. A. Hamad \& A. G. O. Karom, 2001. Brucellosis among animals and human contacts in eastern Sudan. Saudi Medical Journal, 22, 557-579.

Esuruoso, G. O. 1977. Control of brucellosis in Nigeria. In: Proceedings from the $2^{\text {nd }}$ International symposium on Veterinary Epidemiology and Economics, Canberra, Australia.

Falade, S., \& A. H. Hussein, 1997. Brucella seroactivity in Somali goats. Tropical Animal Health \& Production, 17, 93-99.

Godfroid, J., H. C. Scholzc, J. Barbierd, C. Nicolasd, P. Wattiane, D. Fretine, A. M. Whatmoref, A. Cloeckaertg, J. M. Blascoh, I. Moriyoni, C. Saegermanj, J. B. Mumak, A. S. Dahouk, H. Neubauen, \& J. J. Letessond, 2011. Brucellosis at the ani$\mathrm{mal} / \mathrm{ecosystem} / \mathrm{human}$ interface at the beginning of the $21^{\text {st }}$ century. Preventive Veterinary Medicine, doi:10.1016/j.prevet med.2011.04.007.

Holt, H. R., M. M. Eltholth, Y. M. Hegazy, W. F. El-Tras, A. A. Tayel \& J. Gultian, 2011. Brucella spp. Infection in large ruminants in an endemic area of Egypt; crosssectional study investigation, seroprevalence, risk factors and livestock owner's knowledge, attitudes and practice (KAPs). BMC Public Health, 11, 341, doi:10.1186/ 1471-2458-11-341.

Karbo, N. \& W. A. Agyare, 2000. Crop-livestock systems in northern Ghana. Improving crop-livestock systems in West and Central Africa. In: Proceedings from the Workshop on Crop-Livestock Systems in the Dry Savannas of West and Central Af- 
rica, IITA, Ibadan, 22-27 November 1998, pp. 112-126.

Keppie, J. W., A. E. Will \& H. Smith, 1965. The role of erythritol in the tissue localization of the Brucellae. British Journal of Experimental Patholology, 46, 104-108.

Kubuafor, D. K., B. Awumbila, B. D. Akanmori, 2000. Seroprevalence of brucellosis in cattle and humans in the AkwapimSouth district of Ghana: Public health implications. Acta Tropica, 76, 45-48.

Mensal, G. I., K. K. Addo, K. G. Aning, N. Nartey, G. Nipah \& H. Smits 2011. Brucella abortus antibodies in raw cow milk collected from Kraals within the coastal savannah zone of Ghana. Journal of Basic Applied Scientific Research, 1, 942-947.

Megid, J., L.A. Mathias \& C. A. Robles, 2010. Clinical manifestations of brucellosis in domestic animals and humans. Open Veterinary Science Journal, 4, 119-126.

Neilsen, K., \& J. R. Dunkan, 1990. Animal Brucellosis. CRC Press Inc., pp. 173-179.

Miller, J. M., 1991. Quality control of media, reagents and stains. In: Manual of Clinical Microbiology, eds A. Balows, W. J. Hausler Jr., K. L. Herrmann, H. D. Isenberg \& H. J. Shadomy, Washington, D. C., pp. 1203-1225.

Omer, M. K., E. Skjerve, G. Holstad, Z. Woldehiwot, \& A. P. Macmillan, 2000. Prevalence of antibodies to Brucella species in cattle, sheep, goats, horses and camels in the state of Eritrea; influence of husbandry systems. Epidemiology \& Infection, 125, 447-453.

Omer, M. K., T. Asfaw, E. Skjerve, T. Teklegiorgis \& Z. Woldehiwot, 2002. Prevalence of antibodies to Brucella species and risk factors related to high risk occupational groups in Eritrea. Epidemiology \& Infection, 129, 85-91.

Prahad, K., D. K. Singh \& S. B Barbuddhe, 1997. Serological evidenceof brucellosis in sheep and goats. Indian Journal of Animal Science, 67, 180-182.

Seleen, M. N., S. M. Boyle \& N. Sriranganathan, 2010. Brucellosis; a re-emerging zoonosis. Veterinary Microbiology, 140 392-398.

Shehu, L. M., H. Yusuf, A. C. Kudi \& D. U. Kalla, 1999. Seroprevalence of brucellosis in ruminants in Bauchi and environs. $\mathrm{Ni}$ geria Veterinary Journal, 20, 67-74.

Smith, C. M. \& M. D. Sherman, 1996. Brucellosis. In: Goat Medicine, Baltimore, Lea \& Febiger, pp. 423-424.

Statistics Research and Information Directorate (SRID), 2010. Facts and Figures, Ministry of Food and Agriculture (MOFA), Ghana. http://mofa.gov.gh/site/wp-content/uploads/ 2011/10/AGRICULTURE-IN-GHANA-FF2010.pdf

Tanko, P. N., B. O. Emikpe \& M. Y. Sabri 2013. Evaluation of the shedding routes and serological patterns in experimentallyinduced Brucella melitensis infection in dexamethasone-treated and transport-stressed goats, Veterinary World, 6, 686-692.

Teshale, S., Y. Muhie, A. Dagne \& A. Kindanemariam, 2006. Seroprevalence of small ruminant brucellosis in selected districts of Afar and Somali pastoral areas of Eastern Ethiopia: The impact of husbandry practice. Revue de Médecine Vétérinaire, 157, 557-563.

Turkson, P. K. \& D. Q. Boadu, 1992. Epidemiology of bovine brucellosis in the Coastal Savannah zone of Ghana. Acta Tropica, 52, 39-43.

Waghela, S. 1976. Animal brucellosis in Kenya: A review. The Bulletin of Animal Health and Production in Africa, 24, 53-59.

Paper received 15.04.2014; accepted for publication 13.06.2014

\section{Correspondence:}

B. O. Emikpe

Department of Pathobiology, School of Veterinary Medicine, Kwame Nkrumah University of Science and Technology, Kumasi, Ghana. mobile phone: +233549410841 , e-mail: banabis2001@yahoo.com, benabis2001@gmail.com. 